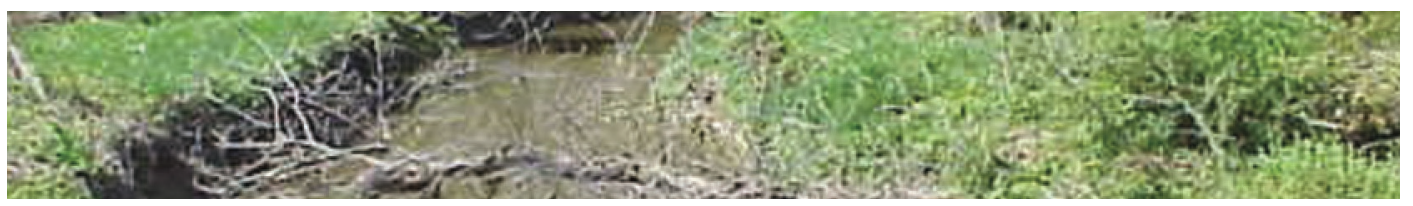

\title{
Morgan Creek Watershed Selected for a National Water-Quality Study
}

The U.S. Geological Survey (USGS) is studying five watersheds across the Nation to better understand how natural factors and agricultural management practices (AMPs) affect the transport of water and chemicals. Natural factors include climate and landscape (soil type, topography, geology), and AMPs include practices related to tillage, irrigation, and chemical application. The study approach is similar in each watershed so that we can compare and contrast the results and more accurately predict conditions in other agricultural settings.

\section{Study objectives}

- Understand the links between the sources of water and agricultural chemicals (nutrients and pesticides) and their behavior and transport through the environment

- Predict the behavior and transport of water and agricultural chemicals in other agricultural areas not being studied

- Evaluate what the study results mean for management of water and water quality in a variety of agricultural settings

\section{We appreciate your help}

We are working with local growers and land owners to gain access to study sites. We also need information about the watershed and about current as well as historical agricultural management practices-past practices also affect concentrations of agricultural chemicals in ground and surface water.

We will report the findings of the study in public meetings and in publications. These findings will provide information that will be useful for improving agricultural management locally and nationally, and will guide future studies in other watersheds.

\section{Why study the Morgan Creek watershed?}

Morgan Creek and the other four watersheds represent nationally important agricultural settings (chemical use, crops, and AMPs) and natural settings (climate, geology, topography, and soils). Morgan Creek, which is part of the Chesapeake Bay watershed, is representative of corn and soybean row cropping in the Atlantic Coastal Plain. Other features relevant to this study:

- Use of agricultural chemicals: Chemicals used include herbicides such as atrazine, simazine, metolachlor, and glyphosate; and fertilizers, both organic and inorganic.

- Distinct natural setting: The nearly flat topography, porous soils, and a permeable surficial aquifer allow water and chemicals to move downward to the water table, discharge to streams, and then move downstream to Chesapeake Bay. The wooded riparian zone along Morgan Creek retards runoff from fields and allows chemicals to break down.

- Variety of agricultural management practices: AMPs include tillage and no-tillage; maintenance of stream buffer zones and grassy waterways (swales); construction of storm retention ponds; use of central pivot irrigation.

- Water-quality issues on the Delmarva Peninsula: Herbicides have been frequently detected in streams and ground water, including drinking-water wells (findings of USGS studies since the 1990s). Some herbicide concentrations were among the highest in agricultural areas sampled across the Nation. Nitrate was frequently detected in domestic drinking-water wells, many of which had nitrate concentrations greater than the Federal drinking-water standard (Judy Denver, USGS).

\section{and natonally, and will guide future studies in other watersheds.}
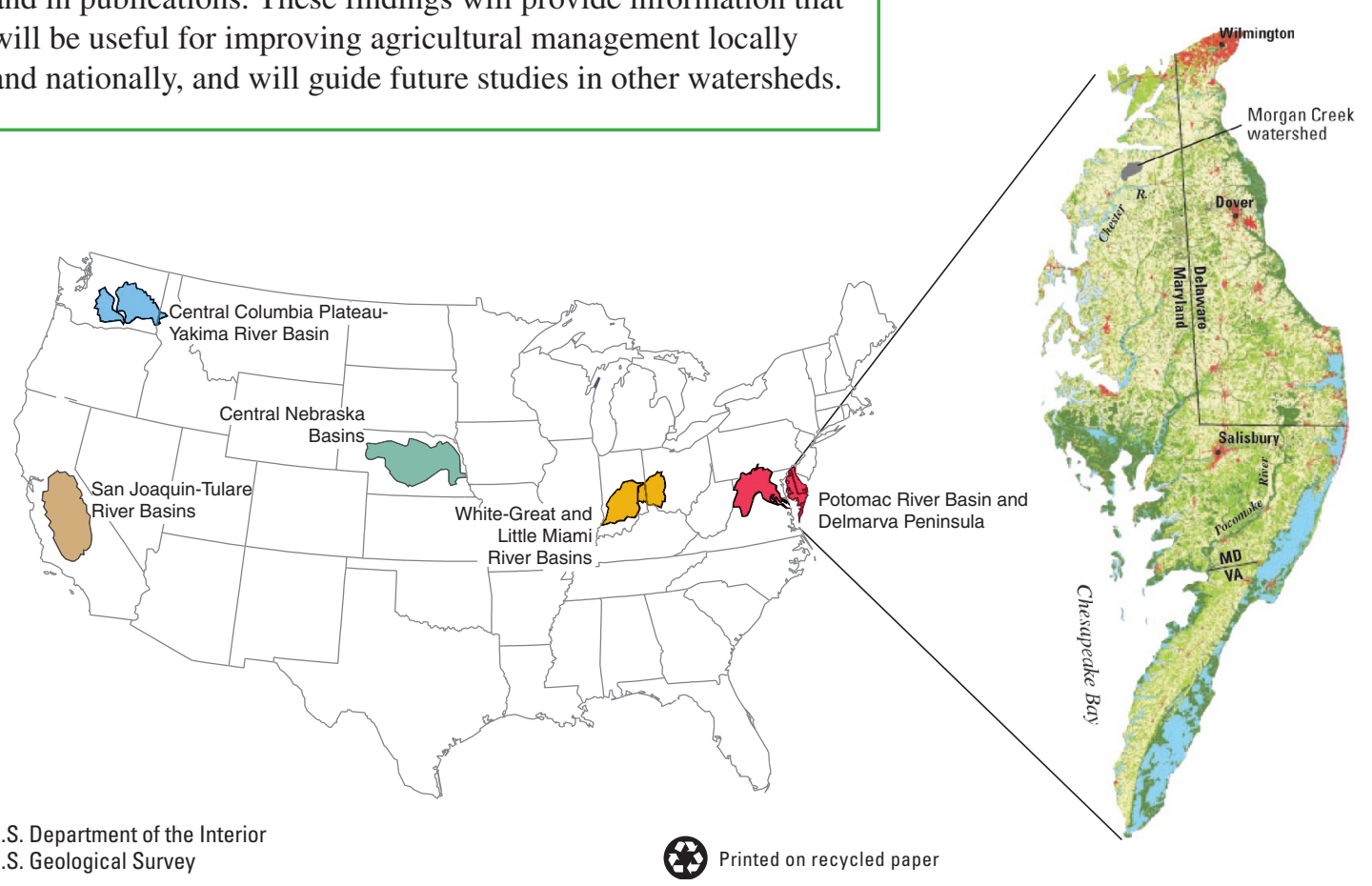

The Morgan Creek watershed on the Delmarva Peninsula is one of five watersheds selected by the USGS National WaterQuality Assessment (NAWQA) Program for a special study of agricultural chemicals and water quality. 
At a typical study site, several methods are used to collect water and chemical samples from the air, soil, surface water, and ground water.

After being applied to the land surface, agricultural chemicals can move upward into the atmosphere, downward through the soil to shallow ground water and underlying aquifers, eventually discharging to streams, or run off across the land into streams, eventually moving downstream to reservoirs and coastal waters. This process can take days, weeks, or even decades if water moves underground through the ground-water system.

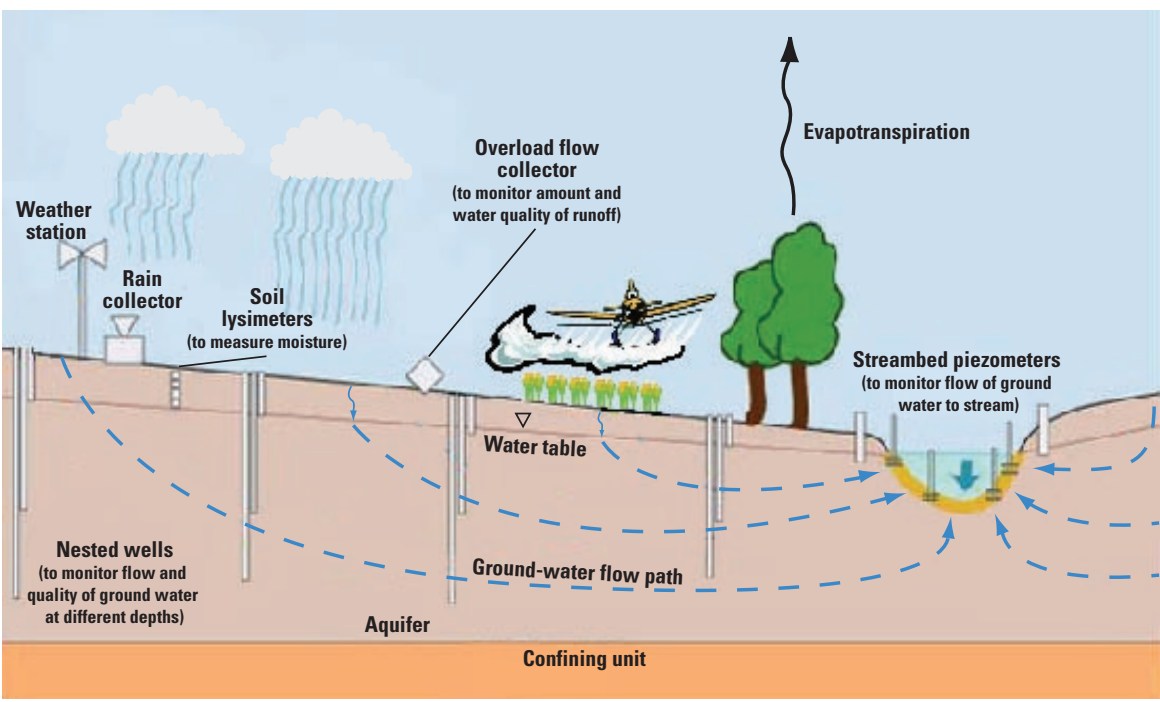

\section{Data Collection in the Morgan Creek Watershed, 2003-2004}

\section{What kind of data \\ Meteorological data, including rainfall, wind speed, solar radiation, and air tem- perature. Soil temperature and moisture \\ Amount of streamflow at Morgan Creek near Kennedyville, MD, gaging station}

Quality of stream water, runoff water, rain water ${ }^{1}$

Ground-water levels in wells

Quality of ground water, soil water, and shallow water in and around streambed/ riparian zone ${ }^{1}$

Quality of sediment in streambed and soils in agricultural fields ${ }^{1}$
Why the data are collected

To determine amount of precipitation and how much water from land surface reaches the water table, how much is lost to evapotranspiration

To interpret water-quality data correctly (the amount of water in streams affects chemical concentrations)

To quantify the transport and behavior of natural and agricultural chemicals

To determine direction of ground-water flow, which affects transport of chemicals

To quantify the transport and behavior of natural and agricultural chemicals

To quantify the storage, behavior, and transport of water and chemicals in the soils and sediment

${ }^{1}$ In this study, water-quality and sediment-quality data include concentrations of nutrients (nitrogen and phosphorous), pesticides and pesticide breakdown products, and natural constituents and properties, including major ions (calcium, magnesium, chloride, etc.), organic carbon, dissolved oxygen, and temperature.

\section{We would like to thank}

U.S. Dept. of Agriculture

Maryland Dept. of Agriculture, Kent County

Soil Conservation District

University of Maryland Cooperative

Extension, Kent County office

\section{For more information}

Tracy Hancock, Lead Scientist, Morgan Creek study

(804) 261-2618, thancock@usgs.gov

Paul Capel, Team Leader, National study (612) 625-3082, capel@usgs.gov
Continuously since 1951 (realtime data available at http://waterdata.usgs.gov/md/nwis/ uv?01493500 )

Several times a year $(>14$ samples) for 2 years, with intensive sampling during application season

At least quarterly in some wells, continuously in others for at least 1 year

At least quarterly for 1 year

At least once during study 